\title{
From Limited to Selected: Towards the Library of Children-Friendly Pesantren in Indonesia
}

\author{
Lilik Istiqoriyah \\ Syarif Hidayatullah State Islamic University Jakarta, Indonesia \\ lilik.istiqoriyah@uinjkt.ac.id
}

\begin{abstract}
This article is based on the uniqueness of pesantren as a religious educational institution known for having high authority and independence, which implements a typical learning culture development especially related to the mastery of religious knowledge for santri who are generally in the system for 24 hours. On the other hand, the right to obtain information for santri and pesantren residents need to be developed in order to meet the needs and keep up with the times. This paper will discuss implementation of children-friendly library as part of the concept of children- friendly pesantren which is being developed in Indonesia in the last decade. The research was conducted by qualitative method in the form of case study conducted to find out how the culture of information access as the spearhead and core of library services as the center of information and learning resource in some pesantren in Indonesia and try to design the concept of library of children-friendly pesantren which is expected. Thus, the library can play an optimal role in supporting the vision, mission and objectives of the pesantren as a religious social system. The research was done by descriptive analysis, where the data and information were obtained by using literature study method, direct observation and interviews with informant that is library manager of pesantren and santri as a user. The results of the study will also illustrate the proposed concept of children- friendly pesantren library in Indonesia that accommodates the needs of users and in accordance with Islamic norms that has been supported by some written commitments and regulations as a policy, the implementation of childrenfriendly learning processes, educators and education personnel trained children's rights, children-friendly facilities and infrastructure, children's participation and also parent, community institutions, businesses, and other stakeholders participation including alumni.
\end{abstract}

Keywords - pesantren library; children- friendly pesantren; information access; children-friendly library; library development

\section{INTRODUCTION}

In order to increase the protection of children in Indonesia, several programs, including Children-Friendly Pesantren/ Pesantren Ramah Anak (PRA), are supported by the Ministry of Women Empowerment and Children Protection/ Kementerian Pemberdayaan Perempuan dan Perlindungan Anak (KPPPA). This is an implementation of the Convention on the Rights of the Children that Indonesia ratified in 1990 , which is also in line with the demands of Law No. 23 of 2003 on Children Protection. This legal umbrella requires protection of children from various forms of violence and the obligation of the parties to provide such protection. In particular, KPPPA is preparing technical guidelines for PRA. This is relevant considering the existence of children in boarding school (pesantren) environment of strategic value because generally the children as students (santri) live and stay 24 hours in the boarding school (pesantren) in the education system. On the other hand, with the condition of students separated from the supervision of parents and families also need to be anticipated the potential for violence in a scale and a particular form or difficulty in dealing with problems more independently faced by them in theirteenagers.

Based on data from the Commission for the Protection of Indonesian Children/ Komisi Perlindungan Anak Indonesia (KPAI) in 2016 and recorded 100 cases of violence against children, even Chairman of Socialization KPAI, Erlinda said, among the 1000 cases, there are 136 cases of violence against children through social media [1]. Previous data from KPAI (2014-2015) showed cases of violence (physical, psychological, sexual and neglect of children) of $10 \%$ committed by teachers, in addition to cases arising from peers. Concerns of parents and the community will be rampant cases of violence, poisoning cases caused by snacks that are contaminated with harmful substances, as well as problems arising from the lack of quantity and quality of facilities / infrastructure, making the education in schools / madrasa is not always a fun experience. Conditions like this can be the trigger of high school dropout cases and even drop out from boarding school as well as students in public schools and madrasa.

Psychological problems are often felt santri are barriers to adjustment, difficulty mingling, difficult to communicate with friends, or with the environment, even bully until the disruption in learning and socializing. Problems can cause stress, so it can affect the duties and responsibilities as a santri. In addition, some students expressed problems related to the social environment ranging from problems with friends, neighbors, and communities around the boarding school because they have to mingle with other people who are different customs in the neighborhood where he lived. They can also experience problems with many rules of boarding schools that must be obeyed, including the limitation of access to information and communication, which makes them feel different from previous conditions. Because of the reasons, santri need information that can help them to overcome these 
problems.

Paradoxically in society there is also a form of violence in children in the community related to access to information, namely that $63 \%$ of parents declare not supervise the content accessed by children, while $55 \%$ of parents give access to ownership of mobile phones and internet (KPPPA, 2015, 7). With this phenomenon it is known that on the one hand the right to inform the children can contain a threat of violence that threatens and will endanger him due to uncontrolled freedom of access or the consequent closed or lack of access to information that is accurate and proportional and controlled.

The existence of libraries that meet the standards and the existence of adequate information access in the pesantren environment is one of the strategic part in the establishment of children-friendly pesantren. Several previous studies have shown that $36 \%$ of traditional pesantren (called dayah) in Aceh do not have one library, and $45 \%$ do not have a single computer raises concerns but also the extent to which they are able to keep data relevant to the running of such facilities. However, the fact that a majority may indicate that salafiyah dayahs are starting to use information technology in supporting their educational activities and work.

Fortunately, on the other hand, in the case of the modern dayahs in Aceh assessed, 92\% had at least one computer, $80 \%$ had a library, besides the other facilities. The fact that $56 \%$ of the modern / integrated dayahs had administrative purposes only. This highlights the fact that traditional dayahs have generally limited facilities. Thus, it is assumed that the availability of libraries and access to information is not evenly distributed among the pesantren in Indonesia.

The most important element for pesantren is the Kiyai, the santri, the mosque, the residence (hut) and the books (yellow book/kitab kuning). Pesantren as well as the school environment is required to provide the library as a source of information for pesantren. From the initial interviews and documentation / literature review it is found that access to students who are the main users to be targeted by libraries is generally very limited. The limitations of the library space used and the time of service, the number and types of collections available, and the lack of access to digital / internet information sources color the culture of information access within the pesantren.

From the above description the problem that will be described in this paper that is: how the culture of information access as the spearhead and the core of library services in some pesantren in Indonesia and how the design of childrenfriendly pesantren program expected to be pursued by pesantren in Indonesia.

\section{METHOD}

This paper is prepared based on field study and literature review on the condition of access to information students at boarding schools. The research approach used is qualitative approach in the form of case study in order to explore the description of the culture or implementation of information access especially in the library, through observation in the pesantren library, and interviews with the parties responsible for that matter. The informants in this study are: Head of Library, librarian / library staff and students/santri. In addition, the researcher uses various supporting documents namely literature and research results containing information related to the topic and documents of technical guidelines of Children-Friendly School (SRA) published by KPPPA as reference comparison. Surveys and interviews were conducted on 5 pesantren libraries namely the Library at Darul Arqam Pesantren in Garut West Java (hereinafter referred to as PDA) representing pesantren which has been supported by UNICEF as a children- friendly pesantren; pesantren in Banten namely Adzkia Islamic School Sarua Tangerang Selatan (hereinafter referred to as PAI), pesantren in Bogor namely Darul Muttaqin Pesantren (hereinafter referred to as PDM), and 2 pesantren in Central Java region namely Al Azhar Pesantren, Cilacap (hereinafter referred to as PAC), and Pesantren Al Quran Al Amin in Pabuaran Purwokerto Utara (hereinafter referred to asPQA).

\section{RESULT AND DISCUSSION}

\section{A. Access Information at the Pesantren Library}

Burnett's (2005, 465) in Shannon M. Oltmann [2, p. 6] mentions the definition of access as" the presence of a robust system through which information is made available to the citizens and others ". Buckland (1991, 78-79) in Shannon [2, p. 8] lists 6 aspects of access-identification, availability, price (to the user), cost (to the provider), understanding, and acceptability-but understands most of these primarily in terms of technological capabilities and requirements [2, pp. 78-79]. With its distinctive character of "religious oriented", pesantren is able to lay the foundations of a strong religious education, with the underlying category of openness to the changes taking place. The santri are not only equipped with an understanding of the teachings of Islam, but also the ability to spread and defend Islam [3].

For that reason, access to information of santri especially in modern pesantren ideally use various sources and media, it can be books, internet search, newspaper, even religious books, then the santri are educated to use the information they have to convey to the society. Hopefully, the santri can become pioneer and agent of change in their respective areas.

From observations and interviews it is known that all libraries surveyed already have library units. Pesantren provides a separate library unit for male and female santri, which is in PDM that serves as a school library as well as a library of cottages / dormitories. PDA Pesantrens serve in separate day schedules between male and females' santri. Other libraries have only 1 library to serve santri together. In general, the library only serves at school hours, but the PAC Library is open from 7:00 to 22:00. Due to these limitations PAI also provides library services that open 24 hours mosque. It can be said that the library service hours are not enough. A good effort from the PAI is exemplary, where the mosque also serves as a place for discussion for santri on actual religious issues that arise in the midst of society by deliberation or other 
terms such as bahtsul masail by referring to the opinions of scholars recorded in both classical and contemporary Islamic religious books [4]. Similarly, PAC efforts open 24-hour service on school holidays.

In terms of location is visibly the PAC Library located in the middle of the dormitory male santri, PAI Library is near the dormitory female santri. This condition supports the facts in which male santri visits dominate in PAC and vice versa in PAI. National Standard Library (SNP) published by National Library of Indonesia [5, p. 4] states that the location of the library ideally located in the center of learning activities and should be easily seen and reached by learners, educators and education personnel. Ideal on-the-spot conditions, in addition to the wider service time allows more equitable access between male and female readers.

Overall, all pesantren already have sufficient collections in various formats and types, both printed and non-printed, such as audiovisual and multimedia as arranged in SNP [5, p. 2]), although there are still libraries that only have collections printed only, namely PQA and PAC. The library also provides a kind of reference collection such as dictionaries, encyclopedias, biographical sources etc. in addition to textbooks and other readings. However, serial publications such as newspapers are not owned / subscribed to PPPA. This condition indicates the weakness of actual information given that newspapers are still a fairly recent source because it is published every day.

Specifically related to fiction collections all libraries claim to have it. Collections are generally in the form of novels, short stories and even comics. This type of collection is also important to serve in the library's re-creative functions along with various other collections including popular knowledge collections, adolescent psychology or religious books so that the library becomes an entertainment area, catalyst and referral for students in finding alternative solutions to the various psychic problems faced in particular as a known teenager facing various dynamics. Akhmad Muchibin and Af'idatul Lathifah [6] in his study also found the limitations of library collections in Pondak Pesantren Futuhiyyah Mranggen Demak. The collection is inadequate because the available is a library material that has been long andmostly contains a book that contains information of Islamic religious knowledge of the caretaker. The lack of library material variants, and the lack of new library materials and poorly organized management, led many santri who did not use the library as their source of information. This is also related to the weaknesses of library management who are still waiting for instructions to add library materials in the library, such as a collection of books by the caretakers of boarding school. Students who want to find information in the school library are only served during school hours. To work on tasks that require other sources the students go outside the boarding school environment in order to access the information through the cafe. Unfortunately, they have the limitations of not always considering the accuracy, relevance, and completeness of the information they find. They do not distinguish between facts, opinions, and viewpoints in the information they need.
One of them they are still using Wikipedia. Santri have not been accustomed to using information resources in various formats such as e-books and other printed works. Factors not provided facilities and also lack of variety of library materials do not require students to be able to grow in search for information, making santri as an incompetent reader. They rarely have the motivation to seek new information.

Regarding the availability of information access via internet from the 5 pesantren surveyed is still low, there is only 1 computer unit provided in library to access internet, including PDA Pesantren and PDM Pesantren which call themselves as digital library. Internet access outside the library is only provided during the subject of Information and Communication Technology (ICT) in the laboratory. Pesantrens also do not provide computers at strategic points such as class, dormitory or nursery. Pesantren Management provides an opportunity for students to access the internet through a cafe outside the pesantren complex when students need information to do their schoolwork. In interviews, however, this opportunity is often used by santri to access information that does not support the interest. Santri more use the internet to open social media sites or other entertainment information. Access to uncontrolled information can be counterproductive because it can lead to access that is inconsistent with Islamic teachings and other norms.

Uniquely in PAC students are allowed to carry and use personal mobile phone on holidays. On the effective day it must be submitted for storage by the teacher /ustadz or ustadzah. Thus, internet access can be more flexible, but still widely used to meet the needs of his actualization by opening social friendship sites. Generally, teachers / ustadz and education personnel have open access rights to information and communication media including handphone and internet access. It is also known that from all locus there is no information literacy program or guidance of tracking and accessing information in a structured method. Coaching is only done by overseeing information seeking activities within the internal environment and directing students to access only information according to the learning needs and does not violate the rules of pesantren and Islamic guidance.

With the development of digital libraries and the potential use of a more optimal collection and interesting library of pesantren should have adopted the concept. In observations and interviews it is known only PDA and PDM that already have digital collections. PDA expect students and teachers to obtain the necessary references either directly on the premises or via the internet. digital collections like Maktabah Syamilah, Maktabah 'Ilmiyah etc. are also owned by PDM although they are only accessible through 1 service computer. It is expected that the library can be organized well and systematically so that directly or indirectly can provide convenience for teaching and learning process in pesantren where the library islocated. 


\section{B. Proposed Draft Component of Library of Children- Friendly Pesantren Program}

If referring to the SRA guidelines, the design of PRA program, especially the fostering and development of Library of Children-Friendly Pesantren Program, in this case can refer to 6 (six) important components namely the written commitment that can be considered as a policy about Children-Friendly Pesantren (PRA), implementation of childfriendly learning process, educators and education personnel trained children's rights, children-friendly facilities and infrastructure, children's participation, and participation of parents, community institutions, business world, and other stakeholders including alumni [7].

1) The PRApolicy: PRA policy is a written commitment in pledges and / or other forms to prevent violence against children in the form of an integrity pact and internal boarding decree (Executive Team Decree and PRA Development Team) are jointly drawn and involve all citizens of the educational unit, kyai / nyai, santri, educators and education personnel including librarians. The drafting of a written policy prohibiting corporal punishment as well as other forms of punishment that undermine the dignity of santri, including a commitment to the right of access to information for santri and other elements, as well as information on grievance mechanisms and the handling of cases of child rights violations. In this case the library should be involved in designing the written commitment, disseminating its information for example through published guidelines and served in libraries and library legislation and information access policies that fulfill santri interests proportionally, such as access to information centers outside pesantren, digital / online information search, social media usage, and others.

2) Implementation of children-friendly learning process: The Library participates actively in a learning process based on equality / partnership, not gender biased, nondiscrimination, provides a fair, accurate, informative picture of local communities and cultures, cares for the rights of the children in a fun, loving and free from discriminatory treatment. In this case the library can play a major role, among others, by applying a longer distribution of time (days and hours of service), not only on the hours of school activities as required in the [5, p. 4] i.e at least 7 hours a day, but also can serve on the hour dormitory activities and holidays. If the separation of service time is required separately then access rules should be fairly defined between male and female santri, and the provision of friendly and professional services without gender bias so that the library becomes a comfortable place to learn, develop insights and current information as well as relaxation, the rights of the librarian from the possibility of violence in the library and surrounding areas, to conduct selection and the provision of library materials that are free from elements of pornography, violence and radicalism, and certainly according to the guidance of Islam.

Collections to support the development of students' talents, interests and creativity, including knowledge of physical and psychological health, including reproductive health information, improvement of soft skill in problem solving, psychological and legal knowledge as well as guidance and counseling, and healthy recreational collections such as Islamic fiction collections and literature contains information on children's rights should also be provided. Collections are developed proportionally to the number and age of santri and other characters, and are well promoted. Librarians should also provide inclusive information and information literacy guidance, including guidelines and restrictions on accessing accurate and reliable digital information. Thus, the library plays a central role in the provision, promotion and guidance of children-friendly information access.

3) Educators and education personnel trained children's rights: Pesantren should ensure the full and complete implementation of training on the rights of children for all elements involved in the pesantren system, from leaders of pesantren, foundations, teacher councils, supervisors, parents, education personnel or administrative staff including librarians or library staff who serve students in the library, to cleaners, and alumni. Specifically SNP [5, p. 5] emphasizes the importance of libraries at least educational libraries equivalent D2 field of library science as a professional dan competence human resource. This is reaffirmed by the Minister of National Education Regulation no. 25 of 2008 that every school / madrasa library has at least one school library personnel / madrasa who qualified high school or equivalent and certified competence of school / madrasa library management from institutions established by the government. It also encourages the head of school / madrasa library qualified as low as Diploma 4 (D4) or undergraduate (S1), or Diploma 2 (D2) of Library and Information Science or D2 of nonScience Library and Information with certain working period or has certificate of competence of school / madrasa library management from institutions established by the government [8].

A good system in learning involves educators and education to encourage and direct students to develop and expand their learning materials independently. This can foster internal motivation of students to study harder and teach about learning how to learn. Librarians and teachers / ustadz and ustadzah spur the ability of information literacy students to be able to search and select information with available resources and determine the validity of so much information, especially information from the virtual world in the process of solving problems, both in the needs of academic and supporters. Librarians play an important role as informed workers are nimble in providing guidance to library users, both programmed and incidental. Increasing the capacity of 
knowledge and sensitivity to children's rights should be improved until all the pesantren have the children's rights values that are internalized in the interaction of education activities and the care of santri. These values will be brought into the environment outside the pesantren with the involvement of santri and alumni who can ensure the protection of children's rights within the pesantren and the wider community.

4) Children-friendly facilities and infrastructure: As well as other infrastructure facilities in pesantren, pesantren library should also be a permanent building that is solid and secure, both in terms of construction, made of safe building materials for students and electrical installation environment, has the first protection and means of handling the possibility of such fires extinguishers and accesses from hazard sites, and have adequate disaster evacuation systems. Libraries should also meet the requirements of good health protection with adequate ventilation and lighting, waste disposal facilities and rules inside and outside the library, meeting the needs of drinking libraries where possible.

The library must also fulfill the comfort element such as the ratio of building area or space, according to [5, p. 3] ie at least $112 \mathrm{~m} 2-280 \mathrm{~m} 2$ from the ratio of the smallest learning group ( 3 groups) to the largest ( 24 groups) with safe temperature and humidity level supporting the preservation of collections and ensuring the health of santri. Another thing that is also very important is good lighting and also tranquility or away from noise. If possible, a special library is available for male and female santri who serve the needs of information access in dormitories, mosques, classrooms or other strategic access points. The availability of a supporting library in addition to the school library also allows access to information becomes easier as it can be prepared to serve students outside school hours in support of dormitory activities and individual needs of santri.

Elements of convenience must also be met with the availability of appropriate means of service such as location and distance between the collection space and reading table, bookshelf height, the distance between shelves, the availability of access roads such as safe and easy to use santri stairs, facilities and evacuation routes, facilities that support the utilization collections and services for the disabled. In fulfillment of the security requirements of the library should be in a safe and easily controlled location within the pesantren environment, the room structure is not physically harmful, exploiting the entire space to avoid empty space potentially negative for the safety of students, the availability of safe means of services such as a dull corner table, such as CCTV and displaying symbols related to (e.g symbol of smoking ban, symbol of prohibition of harassment/ bullying, symbol of gathering points, symbol of female and male, supporting guidelines for disability, etc.), as well as information on complaints mechanisms posted on the walls and others location easily seen by santri.

In particular, health education, safety, convenience, and eligibility should be considered for students with disabilities, if pesantren establishes policy to accept difabel as santri. Of the 5 pesantren surveyed, none have students with disabilities. In the search known pesantren that already serve this group include Pesantren Arafah Cililin Bandung, Difabel Pesantren Al-Amin Babadan Yogyakarta, and Ainul Yakin Pondok Pesantren located in Yogyakarta and Gunungkidul focus on foster children

with disabilities.

5) Children participation: In enhancing the children's participation the library can encourage the creativity of the children by involving in the library friend community, which is a group of santri who have an interest in supporting the improvement of library services by helping to be part of the technical service and user service personnel in their spare time on a scheduled basis. Peer groups can also be formed in the form of Book Lovers Club which has the same interest and commitment to read and review specific field collections especially related to the protection of children's rights or other subjects, including the guidance of research and writing of papers and the proposed improvement of PRA program to pesantren leaders. The library can also encourage the involvement of santri to contribute ideas / suggestions in the preparation of a children-friendly library work program, whether involving aspects of collection development, type and timing of services, service facilities and other activities that support the potential development of santri.

6) Participation of parents, community institutions, businesses, and other stakeholders: The involvement of the parents / guardians of the students should be taken into account in order to ensure the creation of a childrenfriendly pesantren library. The contribution of time, thoughts, personnel, and materials according to their ability to propose work programs, collection procurement, development of services and means to ensure PRA and library program of friendly-chidren pesantren is included in the preparation, implementation and accountability of school / madrasa work programs. Parents can share advice and opinions in library policy making, or assist collection selection activities. They can also periodically and simultaneously oversee the security, safety, and comfort of learners who are served their information needs through libraries, including ensuring healthy internet usage and social media friendly children provided in libraries. Included in the ensured continued intense communication between parents and educational staff in this case librarians for example through private communication or social media.

Furthermore, the involvement of community institutions that can facilitate the realization of library collections and services that support the implementation of PPRA, oversee the security, safety and comfort of students in the library, be proactive in supporting the implementation of friendlychildren pesantren library principles, provide access to students and educators and library staff to visit and access 
information and collections to public libraries and accessible information centers, comparative studies including visiting pesantren or other libraries, in addition to field trips, field work practices, arts and cultural activities needed to support the development of creativity santri.

Business and other stakeholders must also play a role in the implementation of library program of friendly-chidren pesantren in the form of Corporate Social Responsibility (CSR) Program. They can participate not only by facilitating academic activities and providing tuition fees but also donating funds for the development of pesantren libraries from collection, physical and non-physical aspects, human resources development and encourage creative and innovative activities such as literacy training, writing training, document management training, digital library development training, selection training and filtering santri's reading material for mentor/ mudabbir and mudabbirah that companion santri, training of social media usage and mass media, and facilitate of healthy internet access, and others. It can also be pursued to organize the promotion of interesting libraries such as through the best the best library user, race tracking information, writing competition about the library, library book reviews, and others.

The stakeholders contribution can also in assistance in the provision of library facilities and infrastructure services, publication of information on the success of the PRA Library program as part of the PRA program and doing socialization, promotion and dissemination PRA program. They have to being proactive to support efforts to ensure safety, security, filtering information access to violence against children through the internet and other media simultaneously.

The alumni can also provide support for the implementation of PRA activities through the empowerment of the library with its involvement in the stewardship of the educational unit committees that participate in voicing the importance of the role that can be played by the pesantren library through the collection and service and santri based activities. The alumni also play a role in ensuring the socialization of children-friendly values in the community. Imam Safei [9] stated that the library in pesantren has a very important role in self-development effort not only for the santri but also the ustadz and kyai. Through access of diverse library materials available in the pesantren, the students will get a lot of information, knowledge, skills, motivation, and facts contained in the reading. Reading literature is able to grow objective attitude of the santri in discussing a problem.

\section{CONCLUSION}

In principle, Islam is a friendly religion for children/ santri. This is certainly breathing with the spirit of efforts to improve the protection of children's rights which is now increasingly stronger echoes. Consequently, pesantren should carry out educational and nurturing activities as childrenfriendly pesantren, one of them through policies and practices of providing access to information that continues to be developed through library services. The development of frendly-children pesantren libraries was developed, among others, by indicators of written commitments and regulations as a policy, the implementation of children-friendly learning processes, educators and education personnel trained children's rights, children-friendly facilities and infrastructure, children's participation and parents, community institutions, businesses, and other stakeholders participation, including alumni. Thus, libraries and access to selected information become part of a system that optimizes the protection of santri during their stay in pesantren with fulfill the right of information access appropriately. It can be said that information provided, promoted and accessible is childrenfriendly information.

\section{REFERENCES}

[1] D. Hedrian, "Selama 2016, KPAI Catat 1000 Kasus Kekerasan pada Anak," 2016, p. 1, [Online]. Available: http://www.kpai.go.id/berita/8194/ [Accesed: 7-Des-2016].

[2] S. M. Oltman, Information Access. Bloomington: School of Library \& Information Science Indiana University, 2009.

[3] R. Khairul Anwar, Neneng Komariah, and M. Taufiq Rahman. "Pengembangan Konsep Literasi Informasi Santri: Kajian di Pesantren Arafah Cililin Bandung Barat", 2016. [Online]. Available: http://journal.uinsgd.ac.id/index.php/jw/article/view/964/936 p.140

[4] A. M. Fahham, Pendidikan Pesantren: Pola Pengasuhan, Pembentukan Karakter dan Perlindungan Anak, Jakarta: P3DI Setjen DPR RI dan Azza Grafika, 2015, p. 8.

[5] Perpustakaan Nasional Indonesia, Standar Nasional Perpustakaan, Jakarta: Perpustakaan Nasional RI, 2013.

[6] A. Muchibin and Af'idatul Lathifah, "Analisis Kemampuan Literasi Informasi Santri Pondok Pesantren Futuhiyyah Mranggen Demak. Jurnal Ilmu Perpustakaan Jurusan Ilmu Perpustakaan, Fakultas Ilmu Budaya,Universitas Diponegoro, Vol. 5, No. 1 2016. [Online]. Available: http://ejournal3.undip.ac.id/index.php/jip/article/view/15300

[7] Kementrian Pendidikan Nasional Indonesia. "Peraturan Menteri Pendidikan Nasional No. 25 Tahun 2008 tentang Standar Tenaga Perpustakaan Sekolah/Madrasah. Indonesia. Kementerian Pemberdayaan Perempuan dan Perlindungan Anak. (2015). Panduan Pelaksanaan Sekolah Ramah Anak (SRA). Jakarta: Kementerian Pemberdayaan Perempuandan Perlindungan Anak (KPPPA)", 2008. [Online]. https://sekolahramahanak.files.wordpress.com/2013/11/juknisrev4nov2015 psma.pdf p. 14

[8] Kementrian Pendidikan Nasional Indonesia. Peraturan Menteri Pendidikan Nasional No. 25 Tahun 2008 tentang Standar Tenaga Perpustakaan Sekolah/Madrasah, 2008 p. 1

[9] I. Syafe'I, "Dari Tahun ke Tahun, Perpustakaan Pesantren Terus Dibangun," [Online]. Availbale: http://pendis.kemenag.go.id/index.php?a=detilberita\&id=8828\#.Wa5iG NFLcd 